Linguistik Terapan 14 (2) (2017): 152-161

Jurnal Linguistik Terapan Pascasarjana

Available online

http://jurnal.unimed.ac.id/2017/index.php/JLT-Unimed

\title{
THE LI NIHA MAINTENANCE AMONG NIAS TEENAGERS \\ OF ORAHUA MAHASISWA NIAS (OMN) MEDAN IN
}

KELURAHAN LAUCI MEDAN TUNTUNGAN

\author{
RISWAN ZEGA
}

BusminGurning

LinceSihombing

Linguistik Terapan Bahasa Inggris Universitas Negeri Medan

Diterima Agustus 2017; Disetujui Oktober2017; Dipublikasikan Desember 2017

\begin{abstract}
This study explained the Li Niha Maintenance among Teenagers of OrahuaMahasiswaNias $(\mathrm{OMN})$ Medan in Kelurahan Lauci Medan Tuntungan. The objectives were (1) to investigate what maintenance of Li Niha is preserved by the Nias teenagers of OMN Medan (2)to describe how is the Li Niha maintained by the Nias teenagers of OMN Medan (3) to explain the reason why is the Li Niha maintained by the Nias teenagers of OMN Medan. This study applied phenomenological design as a part of qualitative research design. Data were words or utterances of 20 persons teenager of OMN Medan collected through observation and interview techniques. The data were analyzed by using Bogdan \& Biklen, (1992). The findings of this study showed that: (1) four types of Li Niha maintenance preserved by the teenagers of OMN Medan namely strong, dominant, moderate and weak maintenance; (2) four ways of Li Niha maintained by Nias teenagers of OMNMedan,; and (3) five reasons the teenagers of Orahua Mahasiswa Nias (OMN) Medan in Kelurahan Lauci Medan Tuntungan maintain Li Niha.
\end{abstract}

Keywords: Language Shift, Maintenance, Intermarriage, Qualitative 
How to Cite: Zega, Riswan(2017).

The Li Niha Maintenance among Teenagers of Orahua Mahasiswa Nias (OMN) Medan in Kelurahan Lauci Medan Tuntungan. Jurnal Linguistik Terapan Pascasarjana Unimed,14 (2):152-161

ISSN 2407-7410

\section{INTRODUCTION}

Language is needed by human beings to communicate each other since it is a system of communication (Meyer, 2009: 3), Jandt (2003: 40) adds that without language, no culture in the society would be developed because people will lack means of communication by which they can express their ideas one to others.

In contact situations, it is apparent that immigrants live with the dilemma of two conflicting wants: (a) the want to preserve their language as part of their heritage and identity, and (b) the want to be involved within their host community. Enhancing and encouraging the first want may lead to language maintenance, whereas enforcing the second one may lead immigrants, through generations, to lose proficiency in their ethnic language and ultimately shift towards the dominant language.

Commenting on the loss of the minority language, Kaplan and Baldauf (1997: 62) proposed "If both languages can serve all of the same functions and domains, then minority speakers are often drawn to the majority language because it offers greater access to material rewards, employment and economic opportunities. It may also be that there is status to be gained by linguistic and cultural association with the majority group".

Nowadays, the Nias people are spread to many regions like Medan, Sibolga, Jawa, Kalimantan and etc. They out for many reasons, some of them are temporary short-term movement such as study and some of them are long-term movement or have been stayed definitely with their family in certain area such as in Medan to survive.

There are many vernaculars in Medan but this research is focused on Li Niha maintenance by teenagers of OMN Medan in Kelurahan Lauci Medan Tuntungan. As Crystal (1980: 214) states that language maintenance is the ability of an individual speaker or speech community to preserve the use of a language or the traditional form of a language. It means that language maintenance can be activated by practicing it.

A language can be practically used in two ways, spoken and written. In this study the researcher only focuses on Li Niha maintenance which is done orally. It means that the Li Niha maintenance done by 
teenagers of OMNMedan can be seen through how is Li Niha practiced orally. This study focused on the current conditions of the Li Niha maintenance among the teenagers of OMN (Orahua Mahasiswa Nias)Medan in KelurahanLauci Medan Tuntungan.

Based on the description above phenomenon this study focuses on Li Niha maintenance among Nias teenagers in Medan. So that, this study want to find about the maintenance of Li Niha preserved by the Nias teenagers of OMNMedan inKelurahanLauci Medan Tuntungan, about how the Li Nihamaintained by the Nias teenagers of OMNMedan in KelurahanLauci Medan Tuntungan, and why is the Li Niha maintained by the Nias teenagers of OMNMedanKelurahanLauci Medan Tuntungan?

\section{RESEARCH METHODOLOGY}

This study was conducted by applying a descriptive qualitative method. It is a system of inquiry which seeks to build a holistic, largely narrative, description to inform the researcher' understanding of a social or cultural phenomenon (Bogdan \& Biklen, 1992: 58) and instead, the kind of research that produces findings arrived from real-world setting where the "phenomenon of interest unfold naturally" (Patom, 2002: 39).

In this study the researcher use the phenomenological qualitative research design. Phenomenological studiesexamine human experiences through the descriptions provided by the people involved. These experiences are called lived experiences. The goal of phenomenological studies is to describe the meaning that experiences hold for each subject. This type of research is used to study areas in which there is little knowledge (Donalek, 2004).

the researcher used phenomenological qualitative research method to describe what types of LiNiha maintenance found among Nias teenagers of OMNMedan in Kelurahan Lauci Medan Tuntungan, how they maintained the Li Niha applied, and why they maintained Li Niha.

Data also include what others have created and the researcher finds, such as diaries, photographs, official documents, and newspaper articles (Bogdan \& Biklen, 1992: 106). Related to this study the data were the conversations of the 20 participants gotten by observation and their utterances gotten by interview. The source of data in this study is Nias teenagers of OMN Medan in KelurahanLauci Medan Tuntungan.

The technique of data collection is interview and observation and tape recording. Observationis a basic method for obtaining data in qualitative research and is more than just "hanging out." It is a more global type of observation than the systematic, structured observation used in quantitative research.Concerning to this study the technique of collecting the data can be specified asParticipant observation and interview. 
The data have been analyzed by using Bogdan and Biklen's technique. There are some steps of data analysis namely (1) organizing data, (2) breaking data into manageable units, (3) synthesizing data, (4) searching for patterns, (5) discovering what is important and what is to be learned, and (6) deciding what you will tell others (Bogdan and Biklen, 1992: 153). In this research the data have been gotten by two techniques of data collection are observation and interview. So in this research the data have been separated in two parts and then they were analyzed step by step.

(1) Organizing Data

Data

Participant 19 (AT)

Observation (5)

Date $\quad: \quad 27^{\text {th }}$ July 2016

Time : 09.00 p.m.

Address : Jamin Ginting Kelurahan Lauci Medan

AT : Hadia manö nitunö-tunömi andö ba ono matua?

JN : Oh, bro. ae bakha le.

AT : Hana wano rami-rami ami ba nati. So göda ba?

JN : Heheheeh... hadia bale, ira talifusöda ande latunö-tunö wangifira. No awai tugasmö ba Gabe?

AT : Lö manö ni haogögu nasa ua. Ah, ara wönasa da'ö.

JN : Yaia, naobalau mbawa manö dania haogö.

AT : $\quad$ Awai wö sa'e da'ö.

(2) Breaking the data into manageable units

Data 2

RH : Sita, öwa'ö mege lömöi'ö. (Sita, you said just now that you didn't go.)

RH : Hana wa alawö-lawö’ö ba nakhi. Lösalania, aine.

(Why you're reluctant. Never mind, come on.)

(P1. Obs(2).A5)

(3) Synthesizing data

Data 3

RH : Kasih, hezomöi'ödaniabongi?

(Kasih where will you go in this evening?)

RH : Tolamöi’öawögumowöliba?

(Could you like joining me shopping?)

RH : Löaraya'i, ha wowölibarugukosu.

(We are not too long, only buying my t-shirt) 
The data above contained about the conversation between P1 and her friends. In that conversation the P1 asked where Kasih will go at thus night. Her first utterance aimed to make sure that Kasih will not go anywhere because she wanted to ask Kasih joining her to go shopping.

The second and the third utterances of P1 also showed that she used full of Li Niha. This data showed that P1 use full of Li Niha. Concerning to the theory of Lewis, (1996) the type of language maintenance done by this participant (P1) can be categorized as strong Li Niha maintenance.

(4) Searching for patterns

In this step, the researcher found the patterns by separating the similarities and differences characteristics of the data gotten after synthesizing process has been done. The result of this process can be seen as follows:

a. The participant used full of Li Niha from the beginning until the end of the conversation and standardizing Indonesian terms or words can't be translated into Li Niha by avoiding the consonant in the end of the word. Based on the data found strong maintenance has the characteristics as follows:

1) The speaker used full of Li Niha from the beginning until the end of the conversation.

2) The speaker consistently used Li Niha although his/her partner spoke Indonesian to $\operatorname{him} /$ her.

3) The speaker always use Li Niha to Nias people he/she meet.

4) The speaker standardized Indonesian terms or words can't be translated into Li Niha. Based on the data found three ways in standardizing Indonesian terms or words can't be translated into Li Niha.

a) Omitting the consonant in the end of the word. Example:

Hukum becomes huku,sekolah becomes sekola, masukbecomes masu.

b) Changing sound " $P$ " becomes " $f$ ". Example:

Topi becomes tofi,

c) Making the new syllable by adding vowel to avoid the consonant sound. Example:

Pre man becomes fa-re-ma. " $P$ " changed became " $f$ ". Then " $f$ " was added by " $a$ " became "fa".

b. The participants dominantly used Li Niha in their conversation and only used Indonesian language especially in terms or word can't be translated into Li Niha. Based on the data found dominant maintenance has the characteristics as follows:

1) The speaker dominantly used Li Niha in the conversation 
2) The speaker did not standardize Indonesian terms or words can't be translated into $\mathrm{Li}$ Niha.

3) The speaker didn't shifting into Indonesian language although his/her partner responded his/her by using Indonesian language.

c. The participants mixed both of Indonesian language and Li Niha although that word (s) or sentence can be translated into Li Niha. Based on the data found moderate maintenance has the characteristics as follows:

1) The speaker always mixes Li Niha with Indonesian language.

2) The speaker didn't standardize Indonesian terms or words into Li Niha

3) The speaker mixed Indonesian words or sentences into Li Niha although those can be translated.

d. The participants dominantly used Indonesian language and only used Li Niha especially in terms, expressions, or words can't be translated into Indonesian language. Based on the data the weak maintenance has the characteristics as follows:

1) The speaker dominantly used Indonesian language.

2) The speaker used Indonesian language although Nias people speak Li Niha to him/her

3) The speaker only use Li Niha in terms or words can't be translated into Indonesian such as yaahowu, ba, wö, le, afo, etc.

After searching the patterns found that one of them did not match with the types of maintenance stated by Lewis, (1996). The pattern was dominantly using Li Niha in their conversation and only used Indonesian language especially in terms or word can't be translated into Li Niha.

In this case the researcher used term dominant maintenance to representative this pattern because the main point found was "dominantly using Li Niha". So thus pattern was the dominant maintenance.

(5) Discovering what is the important and what is to be learned.

In this step the types of Li Niha maintenance have been classified based on the data patterns found. Then also the participants included in each type have been found. Deciding what you will tell others.

It can be concluded that types of $\mathrm{Li}$ Niha maintenance preserved by teenagers of OrahuaMahasiswaNias (OMN) Medan in KelurahanLauci Medan Tuntungan are: 6 participants included in strong maintenance, 6 participants included in dominant maintenance, 4 participants included in moderate maintenance, and 4 participants included in weak maintenance. 


\section{FINDINGS AND DISCUSSIONS}

\section{Findings}

After the analysis conducted, some findings were found as the answer for the research that can be seen as follows:

(1) Four types of Li Niha maintenance preserved by the teenagers of OrahuaMahasiswaNias (OMN) Medan in KelurahanLauci Medan Tuntungannamely strong maintenance, dominantly maintenance, moderate and weak maintenance.

(2) The ways of Li Niha maintained by Teenagers of OMN Medan in KelurahanLauci Medan Tuntungan MaintainLi Nihawere:

a. Six participants $(1,9,2,15,17,19)$ consistently used full of Li Niha although their partner spoke Indonesian language to them and standardize terms or words of Indonesian language can't be translated into Li Niha.

b. Six participants with $(3,5,12,13,14,18)$ dominantly use Li Niha and directly use the terms or words of Indonesian language without standardized into Li Niha.

c. Four participants $(2,4,7,10)$ mixing Li Niha with Indonesian language.

d. Four participants $(8,16,20,6)$ dominantly use Indonesian language and use the terms or words of Li Niha can be translated into Indonesian language.

(3) Five reasons of Li Niha maintained by Teenagers of OMN Medan in KelurahanLauci Medan Tuntungan. Each participant stated that she/he has the different reasons with others. Then each participant has more than one reason in maintaining Li Niha that reported as follows:
a. it's their heritage language
b. in order to show that they are not arrogant to Nias people
c. in order to show the closeness with Nias people
d. in order to show their identity as Nias people
e. in order that he/she can talk to Nias people (oldest people) who cannot speak in Indonesian.

\section{Discussion}

Language maintenance was not a new issue. There were some researchers did researches related to this case but different subject and object. This study was about the types of language maintenance. From some of previews studies about language maintenance, one of them have the similar case with this study entitled "Language Maintenance in Seven K'iche' Communities", written by Lewis(1996).

The finding of his research indicated that from six of these communities (Chichicastenango, Cunén, Santa Cruz del Quiché, Sacapulas, San Andrés Sajcabajá, and Totonicapán) are reported have different levels of K'iche' maintenance and have different patterns of language use. Based on thus 
research finding showed that levels of language maintenance were categorized as Weak, Moderate and Strong. While this study was about the Li Niha Maintenance Among the Teenagers of OMN Medan in KelurahanLauci Medan Tuntungan. This study found that there were four types of Li Niha maintenance namely strong, dominant, moderate and weak maintenance.

Based on the Lewis' findings stated that (1) strong maintenance is categorized when the speaker use full his/her heritage language in conversation while in this study showed that the speaker not only used full of their heritage language but also standardized their second language into their heritage language; (2) moderate maintenance is categorized when the speaker did code-mixing same as the finding of this study; (3) weak maintenance is categorized when the speaker dominantly used the second language. While in this study showed the weak maintenance is categorized when the speaker dominantly used Indonesian language and did not standardize Li Niha terms or words that can't be translated into Indonesian language.

Beside that in this finding showed the new types, dominant maintenance. It is categorized when the speaker dominantly used Li Niha and didn't standardize Indonesian terms or words can't be translated into Li Niha.

Veltman (1991: 147) asserts that "language maintenance is the practice of speaking one mother tongue throughout one lifetime as the only language in daily use". From the finding of this research showed that the Nias teenagers of OMNMedan in KelurahanLauci Medan Tuntungan still speak their mother tongue although they are minority speakers in Medan.

There are some efforts that can be done in order to maintain a certain language. According to Fishman (2001) there eight stages of language maintenance process are:

(1) Acquisition of the language by adult, who in effect act as language apprentices (recommended where most of the remaining speakers of the language are elderly and socially isolated other speaker of the language).

(2) Create a socially integrated population of active speakers or users of the language rather than the written language.

(3) In localities where there are a reasonable number of people habitually using the language, encourage the informal use of the language among people of all age group and within families and bolster its daily use through the establishment of local neighborhood institutions in which the language is encouraged, protected and (in certain context at least) used exclusively.

(4) In areas where oral competence in the language has been achieved in all ages groups encourage literacy in the language but it does not depend upon assistance from (or good will of) the state education system. 
(5) Where the state permits it, and where numbers warrant, encourage the use of the language in compulsory state education.

(6) Where the above stages have been achieved and consolidated, encourage the use of the language in workplace (lower workshop here) local.

(7) Where the above stages have been achieved and consolidated encourage use of the language in local government services and mass media.

(8) Where the above stages have been achieved and consolidated encourage use of the language in higher education, government etc.

The eight stages above can't be decided if they have been applied in Li Niha maintenance. Because in this study only focused on how Nias teenagers maintained their language based on the types they applied. As finding showed that the ways of Li Niha maintained.

Hong (2016) have done research entitled "Heritage Language Maintenance and Development among Asian Immigrant Families in Canada". Asian immigrant families across the three ethnic groups are reported to actively support their children's heritage language maintenance overall, the degree of their involvement and focal points for heritage language education are found to differ owing to linguistic characteristics, family environment, and absence or existence of stable ethnic communities in a larger society. While in this study found that the teenagers' parents did not support them to use their heritage language.

Talking about the reasons of language maintenance, by Crystal (1997) language maintenance should be done in order to (1) creating cultural diversity, (2) keep ethnic identity, (3) enable social adaptability, (4) increasing security for the children psychologically, (5) increase the sensitivity of linguistic. While this study found that there were five reasons of language maintenance ( $\mathrm{Li}$ Niha maintenance) namely; (1) it's their heritage language, (2) to show that they are not arrogant to Nias people, (3) to show the closeness with Nias people, (4) to show their identity, and (5) in order that he/she can talk to Nias people (oldest people) who cannot speak in Indonesian.

Based on the result of this research almost of the reasons of language maintenance stated by Crystal did not showed the same with the reason of Li Niha maintenance done by the teenagers of OMNMedan in KelurahanLauci Medan Tuntungan. It means that any subjects have the different reasons in maintaining their language.

\section{REFERENCES}

Baskin, J. F. (2015). Turkish Women in Alsace: Language Maintenance and Integration. Review of Social Studies (RoSS), Vol.2, No.2, Autumn 2015 (pp.67-84). USA: Indiana University. 
Bogdan, C. O., \& Biklen, K. S. (1992). Qualitative Research for Eduction: An Introduction to Theory and Methods. Boston: Allyn and Bacon.

Crystal, D. (1997). Language Death. Cambridge: Cambridge: Cambridge University Press.

Crystal, D. (2003). Language Death. Cambridge: Cambridge University Press.

Donalek, J. G. (2004). Demystifying Nursing Research: Phenomenology as a Qualitative Research Method. Urologic Nursing, 24, 516-517.

Holmes, (2001). An Introduction to Sociolinguistics: Second Edition: Person Edition Limited.

Jandt. F. E. (2003). Intercultural Communication: An Introduction. London: Sage Publication.

Jonse, Mark, Tol, Sijmen. (2003). Language Death and Language Maintenance: Theoretical, Practical and Descriptive Approaches. Philadelphia: John Benjamin.

Kaplan, Robert, B. and Baldauf, Richard B. (1997). Language Planning from Practice to Theory. Sydney: Multilingual Metters.

Lewis, H. (2012). Language Maintenance: A Liberal Approach. IPSA World Congress (pp. 1-24). Wales, U.K: Aberystwyth University.

Lewis, P. M. (1996). Language Maintenance in Seven K'iche' Communities: LSA Parasession, 2, (pp. 1 13)

Meyer, F. C. (2009).Introducing English Linguistics. Cambridge: Cambridge University Press.

Patton, M. Q. (2002). Qualitative Evaluation and Research Methods ( $3^{\text {rd }}$ ed). Thousand Oaks, CA: Sage Publications.

Veltman, C. (1991). Theory and Method in the Study of Language Shift. In J.R. Dow (Ed.), Language and Ethnicity: Focus Schrift in Honour of Joshua, A. Fishman (pp. 145- 167). Philadelphia: John Benjamins Publishing Company. 